\title{
YOUTH ENVIRONMENTAL COMPLAINTS IN BAHAWALPUR CITY, PAKISTAN: AN INFORMATIONAL INTERVENTION FOR LOCAL ENVIRONMENTAL GOVERNANCE
}

\author{
Sana Arshad, Adila Shafqat*, Asad Ali Khan, Quaratulain Safdar \\ Department of Geography, The Islamia University Bahawalpur, Pakistan
}

\begin{abstract}
The paper comprises the concept of environmental governance, and the role played by institutions and citizens particularly youth dealing with environmental problems complaints. It represents an initial attempt to construct a fresh approach to the field of environmental governance by considering youth complaints as an important source of information for the management authorities. Local organizations and institutions are considered in order to collect information about the number and types of complaints regarding environmental problems. Moreover, the resolved and unresolved complaints data is also collected through Tehsil Municipal Administration complaints cell and particular actions are analysed. The complaints submitted by citizens are categorized on the basis of age structure. Results clearly show the interest of youth regarding environmental problems as well as the local authorities response of these complaints are recorded in the through textual interviews results. The submitted complaints made it very easy for the authorities to analyse the environmental problems at union council level and resolved complaints shows the attention of local authorities towards these problems. Youth as being educated and most active part of the community can play its vital role in this process. Youth, by its participation can make this complaint process an important avenue for community participation in environmental governance and policies. The paper tries to build a new idea about youth involvement by analysing their interests in the city related environmental problems. It gives an approach of developing collaboration between youth community and municipality for better planning concerning the problems of the city.
\end{abstract}

Key words: Youth, Environmental Governance, Environmental Problems, Tehsil Municipal Administration (TMA), Bahawalpur.

Article Info: Manuscript Received: November 15, 2012; Revised: May 5, 2013; Accepted: May 15, 2013; Online: May $25,2013$.

\section{Introduction}

Local authorities of the cities in developing countries face many environmental problems such as the management of solid waste, sewerage collection and treatment of , road construction and expansion, increasing poverty and service provisions. These have developed as serious environmental problems in areas where there is a rapid expansion of urban population together with little or no environmental implication, imposing a big responsibility on city management authorities. Hence, management of environmental problems is one of the most important challenge faced by local authorities that has become

\footnotetext{
* Corresponding author:

Address: Department of Geography, Baghdad ul jadeed campus

Faculty of Science, The Islmia University Bahawalpur 63100,

Pakistan.

Telephone: oog2-62-9255561

Email: adila.shafqat@iub.edu.pk
}

complex and expensive requiring development of institutional arrangements (Hasan and Ali, 1992). The increase in the citizen's understanding of environmental issues, and the consequent demand for higher urban environmental quality standards, have acted, along with other factors, to mobilize public complaints over local governments (Carvalho and Fidélis, 2009a). Hence environmental complaints should be seen a relevant medium to characterize and evaluate citizens' concerns as well as the local authority's response based on their expectations (Carvalho and Fidélis, 2009b). Citizen's involvement in environmental governance is not a new idea; there has been considerable emphasis on increasing opportunities for citizens to actively participate in local environmental governance (Markell, 2004). In discussing the role of citizens, youth can be considered as significant actor of the society in short 
and long term action and decisions by authorities. (Driskell, 2002).

The research focuses on the concept of local environmental governance, the role played by youth through complaints, and the challenges of local environmental governance. To support the review, relevant studies related to environmental concerns and complaints submitted by youth to local authority are presented and integrated. Finally an analysis between areas of intervention and the calls for the solution of environmental problems, partially revealed through the complaints submitted by youth, is shown to support the potential and effectiveness of this type of public feedback. The aim of the study is to analyse the youth complaints as a source of information for local authorities, and access the complaints process of the municipality.

In brief, this study aims to answer the following questions:

- What information can youth complaints provide?

- Can these be considered relevant tools for local environmental governance?

- How are local governments managing and responding to these complaints?

\section{Environmental Governance at local level}

The term governance, itself, is a recent concept that has only been introduced into the the academic literature since the early 1990s (Qi et al., 2007). Based on the well-known governance definition from World Bank, the academic literature usually recognizes it as "the exercise of political authority and the use of institutional resources to manage society's problems and affairs" (Harman, 2005). authors (Ostrom, 1990) (Paavola, 2007) looked at "governance" as encompassing and focusing on the role of collective action, the problems of managing common resources and emphasizing the role of voluntary organizations in resolving them.

Environmental governance can be defined generically as a set of interrelated processes where the individuals, in their different roles, make decisions about the environment (Dorcey and McDaniel, 2001, quoted in (Gore et al., 2004) . It is also recognized as a set of regulatory processes, mechanisms and organizations in which political actors influence environmental actions and outcomes (Lemos and Agrawal, 2006). moderating the concepts of "governance" and "environmental governance" by considering the former as a system of rules through which an organization or society works, and the latter as a system of rules and practices through which a society manages the environment. The concept of environmental governance emphasizes the changing nature of local authorities; that is, governance is usually thought to point beyond government to include all of the collective actors who are brought into a system to address or manage a given issue (Friedmann and University of British Columbia. Institute of Asian). "Interrelated set of processes within which individuals in varied roles make decisions about the environment" (Frank, 2006) They go on to state, therefore, that environmental governance "is that subset of processes relating to decision making with respect to the biophysical environment". (Gore et al., 2004)

Governing environmental problems in a local perspective is a crucial challenge local authorities face since they provide essential services for society and play an important role in sustainability implementation, together with national authorities. Yet, local knowledge and experience can produce positive effects in the way local governments cope with environmental challenges, enabling local authorities to address their efforts to solve environmental problems which significantly affect citizens.

\section{Role of youth in local environment governance}

Successful solutions to environmental problems can only be achieved by not only governmental intervention and enforceable regulations, but also through participation of the whole society. Different segments of society can play their significant role in standardizing the environmental quality and solving environmental problems. Active population specifically youth can play major role in this process.

Generally the difference between adult and youth is not considered significant, but both are defined differently. In Population Geography the age structure is divided into three subgroups as young, adults and old.

- Young age group includes o-14 years of age.

- The adult age group includes 15 to 64 years of age

- The last, old age group includes above 64 years of age. (Qazi, 2006)

The adult age group is considered as the most mobile, economically productive and biologically most reproductive. (Qazi, 2006). Youth is the major subgroup that fall under the category of adults. The official definition of youth by United Nations general assembly in 1999 is "All persons falling between the ages of fifteen and twenty four included is considered as youth"(Friedmann and University of British Columbia. Institute of Asian).

The vast majority of the world's youth some 87 per cent lives in developing countries and are currently facing a lot of challenges regarding limited access to resources, education, training, employment 
and economic development opportunities (Nations, 2010). According to United Nations Development Program, Pakistan has a large population that can be categorized as falling within the Uinted Nation's definition of youth. An estimated 103 million Pakistanis, or $63 \%$ of the population, fall under the age of 25 years. Youth Literacy Rate is estimated to be $53 \%$. According to UNDP statistics, the total population of Pakistan in 2007 was 164 million in which youth makes 36 million of the total. (UNDP, 2011)

Public participation has been a major topic of debate in developed and developing countries regarding environmental governance. Citizen involvement in decision making has been acknowledged as a potential and partial solution for environmental problems.(Renn et al., 1995)

The environmental management is characterized by overlapping and shared authority between governments, and between state, non-state, and inter-state actors. Such overlap arises from the complex spatial structure of environmental processes, and because effective environmental governance depends on the behaviour and knowledge of many diverse actors, which the state lacks the knowledge and authority to specify (Gauthier, 2003).

When citizens are collecting information regarding the problems they face, youth are considered as a dominant group from the all citizens of any region. Dasgupta (et al., 1997) discussed youth complaints as a cheap and low cost information source for environmental governance. In a case study of China's environmental problems, they discussed the education as an important factor for recognizing the importance of complaints. Considering the Wheeler's et al (1997) study of China, the importance of educated youth of all citizens can be highlighted. Youth can participate as an important source of information for environmental management strategies from local to broad level. Another study by (Johnson et al., 2007) on China reported Chinese youth as an effective participant for environment, community and also for themselves. Being the active participants in environmental governance process, young people have potential and innovative ideas to enhance the environmental quality. If streamlined properly they can be very useful in locating the environmental problems and finding their possible solutions. 2010 United Nations World Youth Report on the theme of "Youth and Climate change" describes the role of youth in four ways

1. Informing and educating young people

2. Gathering information from young people

3. Consulting with young people

4. Involving young people

5. Establishing collaborative partnerships with young people
Complaints regarding environmental problems: as a new source of information

Authorities can collect information about city environmental problems and monitor them through following ways.

1. Direct visits to the all areas of the city or those with potentially higher risk regarding environmental problem

2. Monitoring by local public and then informing as a complaint to local authority

3. Modern instruments such as satellite imagery, environmental sensors, social media monitoring etc.

Many studies have been conducted about the public feedback and citizen complaints about municipality concerns and environmental problems. So the idea of information gathered from complaints is not new. Improper management of public services and environment infrastructure problems are the most significant reasons for the dissatisfaction that drove people to lodge complaints. (Carvalho, D. S., \& Fidélis, T. 2011)

Cantrell, (1980)in a study about environmental complaints received by the Prince Williams County, Virginia, Health Department found that most of them were waste-related (e.g. refuse, sewage, pest). Other types, having political, social or even sympathetic and personal motivations, were also identified. Huang and Miller, (2006), believe that citizen complaints may influence the environmental regulatory enforcement and compliance, producing helpful policy implications for regulatory enforcement agencies. Community characteristics as sex age (Kosecik and Sagbas, 2004) literacy rate (Carvalho and Fidélis, 2009b, Dasgupta and Wheeler, 1997) occupation and income (Bonaiuto et al., 2006) are considered to be influential factors in pattern of complaints and public attitude towards municipality.

In this study, youth (cohort 15-24 age, discussed in methodology section) complaints regarding environmental matters submitted to governmental authorities are considered formal and non-organized comments and demands, which can be seen as a direct consequence of the perception and subsequent reaction to environmental problems. Information from these complaints can act as an important indicator of environmental governance performance, especially at the local level, with respect to public concerns about local environmental problems.

This article comprises a research methodology for the study of environmental complaints at the local level as an indicator of youth perception of environmental quality and a promising instrument for the evaluation of local governance performance. Besides the typology of environmental problems, the actors involved, the territorial pattern of these 
protests, and the performance of the Tehsil Municipal Administration (as the receptor of public complaints) towards the resolution of complaints, were also analyzed.

\section{Methodology}

The aim of the study is to take the complaints as a valid source of information for local Authorities. The data is of primary source,collected directly from Tehsil Municipal Administration of Bahawalpur City about the complaints received from local community of the city. Municipal Corporation at Tehsil level in Pakistan is known as Tehsil Municipal Administration (TMA). TMA in every Tehsil is headed by Tehsil Nazim. It is responsible for spatial planning and spatial services, exclusively working with union councils and other civil society and private organizations. (Shafqat, 2011) The functional chart of TMA Bahawalpur is as follows

Applications from various union councils of the city are received by the TMA complaint cell. Complaints receiving process of TMA is informal and unstructured. Local community submits its complaint by meeting TMA relevant official and they enter the complaint directly in Complaint register. The collected data for the study is compiled from the manually maintained registers from the month of March 2010 to March 2011 and categorized along age groups. The complaints applications are analysed according to citizen's age group in order to examine the youth interest in addressing various environmental issues of the city.

In order to examine the distribution of environmental problems in study area, complaints received at Municipal Administration are mapped. Union council's layers is taken in the form of analogue data from TMA and digitized at a scale of 1 : 54,676 using Geographic coordinate system WGCS 1984 and complaints are entered in the database using Arcmap 9.3. In depth interviews are conducted with complaints receiving officials of the TMA to better examine the situation of complaints monitoring process.

\section{Study Area}

The study area of research is Bahawalpur situated $60 \mathrm{~km}$ south of Multan on the left side of Sutluj river having an area extent 9,620 hectares. (World Bank and Government. of Punjab, 20o6).According to 1998 census report, total area of Bahawalpur District was 24,830 Square Kilometer. Out of which TMA Bahawalpur comprised of 2,372 square kilometer. Climatically area lies in semiarid continental region and characterized by seasonal fluctuation in temperature and rainfall. (Tehsil Municipal Administration Bahawalpur) For administrative purpose, city is divided into 18 Union Councils (A corporate body headed by Union Nazim for supporting the functions of Tehsil Municipal Administration, Town Municipal Administration and District Government).

According to the Census Report of 1998, Bahawalpur had a total population of 408,395. The average household size was 7.35 persons. The average growth rate $1981-1998$ was $4.93 \%$.

According to demographic profile of TMA Bahawalpur, Population of Bahawalpur under TMA by sex is as follows

Table 1. Population by Sex

\begin{tabular}{lll}
\hline Total & Male & Female \\
806,580 & 430,703 & 375,877 \\
\hline
\end{tabular}

Source: Tehsil Municipal Administration Bahawalpur

Table 2 gives the statistics of young population of the TMA Bahawalpur, which shows that Bahawalpur comprises of good percentage of young and active population.

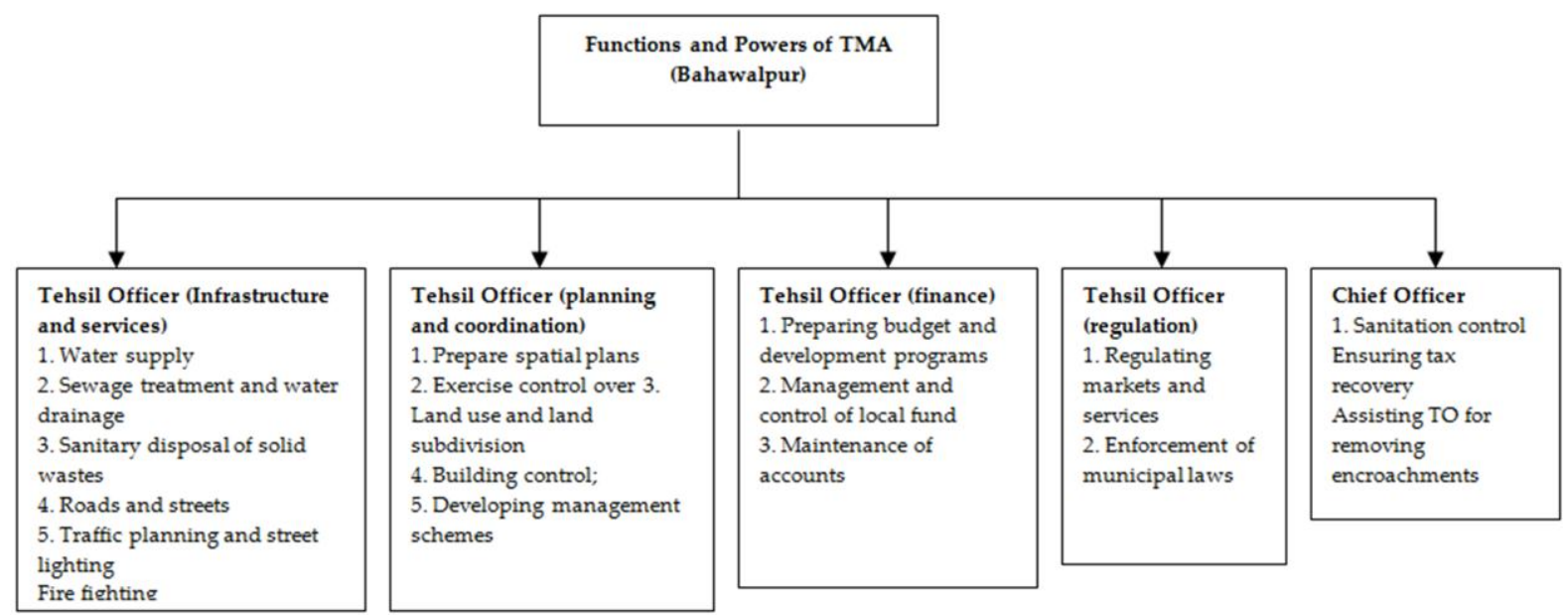

Figure 1. Administrative Division of Tehsil Municipal Administration 
Table 2. Age Groups distribution in Bahawalpur

\begin{tabular}{lllllll}
\hline Group & (In & Total & & & Urban & \\
Years) & Both Sexes & Male & Female & Both Sexes & Male & Female \\
Under 1 & 17,046 & 8,641 & 8,405 & 8,525 & 4,348 & 4,177 \\
Under 5 & 115,799 & 59,241 & 56,558 & 56,647 & 28,933 & 27,714 \\
$05-09$ & 127,966 & 66,636 & 61,330 & 63,255 & 32,832 & 30,423 \\
$10-14$ & 105,519 & 55,926 & 49,593 & 55,904 & 29,335 & 26,569 \\
$15-19$ & 80,652 & 42,155 & 38,497 & 45,197 & 23,543 & 21,654 \\
$20-24$ & 72,267 & 37,741 & 34,526 & 39,721 & 21,481 & 18,240 \\
$25-29$ & 65,297 & 36,485 & 28,812 & 37,055 & 21,928 & 15,127 \\
$30-34$ & 57,459 & 33,518 & 23,941 & 33,273 & 20,382 & 12,891 \\
$35-39$ & 40,872 & 23,815 & 17,057 & 24,464 & 14,825 & 9,639 \\
$40-44$ & 35,854 & 18,618 & 17,236 & 20,272 & 10,987 & 9,285 \\
$45 \&$ above & 104,895 & 56,568 & 48,327 & 53,448 & 28,872 & 24,576 \\
& & & & & & \\
\hline
\end{tabular}

Source: Tehsil Municipal Administration Bahawalpur

\section{Results and Discussion}

The major environmental problems of the Bahawalpur City are listed by young citizens in their complaints. However, general key issues of the city include improper sewerage system, and effluents disposal along with solid wastes. The listed problems in the complaints are present in the table 3.

For the current study, information gathering from young people is considered as a significant participatory role for environment management and governance. As young people are the most active group of population and can access the problems in the surrounding environmentquicker. Therefore, local government can gather information regarding the environment problems quicker from the young citizens.

The complaints applications are analysed according to the Union councils and age groups of the citizens. Table 5 shows different categories of environment problems and number of complaints received from citizens. The age groups of citizens are categorized into 3 subgroups. The age group 15 to 29 years of age is considered as young active share of population. However the role of citizens from all groups cannot be denied when good governance is considered. As the administrative functions of TMA is categorized into different subgroups. Therefore, the complaints are submitted according to actions and responsibilities of every division. As fig 1 shows the responsibilities of Tehsil officer (infrastructure and service) regarding water supply, sewage treatment and sanitary disposal etc. therefore the complaints regarding such problems are submitted in this division for further action. Table 4 shows the details of every complaint according to age groups of citizens and represented in figure 2.
Table 3: Environment problems of Bahawalpur

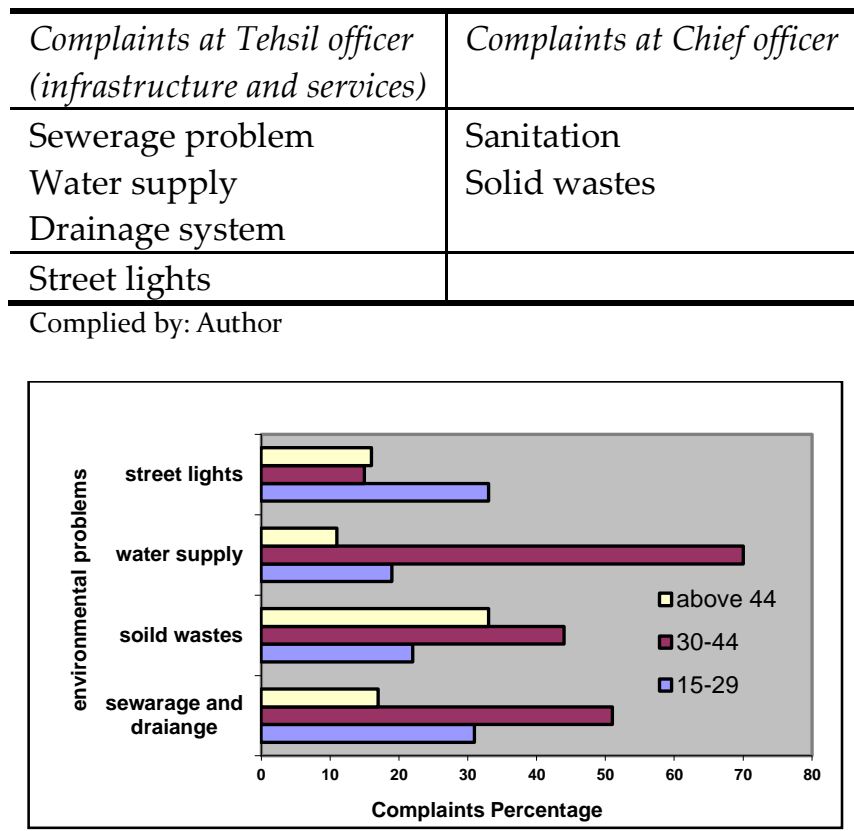

Figure 2. Complaints received at TMA from different age groups

Table 4 shows that the highest number of complaints is regarding sewerage and drainage problem of the city. The existing Sewerage System (including the open drains) covers only $50 \%$ of the built area. The piped sewers have only been provided on the main roads, and most of the streets are provided with open drains only, which are connected to sewers. Presently there is no facility for treatment of the waste water. The wastewater pumped from disposal stations is utilized without any treatment by farmers for irrigation, presenting a potential health hazard. The excess wastewater from the disposal stations is pumped either into the Sutlej River or into 
Table 4: Distribution of complaints received from different age groups

\begin{tabular}{|c|c|c|c|c|c|c|c|}
\hline \multirow{2}{*}{$\begin{array}{l}\text { Age } \\
\text { groups }\end{array}$} & \multicolumn{3}{|c|}{ Complaints received (chief Officer) } & \multicolumn{4}{|c|}{ Complaints received (infrastructure $\mathcal{E}$ services } \\
\hline & $\begin{array}{c}\text { Sewerage and } \\
\text { drainage }\end{array}$ & $\begin{array}{c}\text { Solid } \\
\text { wastes }\end{array}$ & Total & $\begin{array}{c}\text { Sewage and water } \\
\text { drainage }\end{array}$ & $\begin{array}{l}\text { Water } \\
\text { supply }\end{array}$ & $\begin{array}{l}\text { Street } \\
\text { lights }\end{array}$ & Total \\
\hline $15-29$ & 08 & 06 & 14 & 74 & 9 & 10 & 93 \\
\hline $30-44$ & 19 & 12 & 31 & 115 & 33 & 15 & 166 \\
\hline $\begin{array}{l}\text { Above } \\
44\end{array}$ & 09 & 09 & 18 & 36 & 5 & 5 & 46 \\
\hline
\end{tabular}

canals. (World Bank and Government of Punjab, 2006)

Table 4 also shows that total number of complaints received from the age group of 15 to 29 years is near to 107 and from the age group of 30 to 44 years is near to 197. However, the complaints received from the younger age group show their interest and understanding about various problems of the city. Louis Chawla and David Driskel describes in their study that young people show ability and willingness to be involved with in tackling community problems and being also willing to effectively work with adults for decision making.(Checkoway and Gutiérrez, 2006).

Share of complaints submitted by different age groups is shown in figure 3 , which reveals a significant contribution of youth for the submission of complaints. The younger age group submitted $31 \%$ complaints about sewerage and drainage, 22\% complaints about solid wastes, 19\% complaints about water supply and 33\% complaints about street lights

The number of maximum complaints is received from core city of the Union Councils (comprising councils number 3,4 and 5 ). The number of complaints received from these areas is large due to more environmental problems especially the predominating problems related to these areas are sewerage system and open drains in Union Council 3, and 4. However, some part of Union Council 5 is developed and has problem that most of the open spaces are converted into dumping sites of solid wastes. The minimum number of complaints is received from areas having less residential settlement and municipal services supply from Union Council's number 9, 14, 16 and 18. Figure 3 clearly shows the concentration of environmental problems in the core and middle area of the city being related to the received complaints.

After sewerage and drainage the $2^{\text {nd }}$ most highlighted problem of the city identified by youth complaints is water supply of the city. Resources of drinking water limitations and other daily purposes are very limited as ground water in the Municipal area is mostly saline except along the canals and river. The depth of water table varied from 5.5 to 10 meters. Moreover the quality of water supplied is another major issue of the city. The major key issues of the city regarding water problems are following

- Low coverage of piped sewerage system

- Low coverage of the water supply system, very low number of official connections (though a large number of illegal connections)

- Most water supplied is polluted, and there is a widespread problem of high levels of arsenic in the water

- No monitoring of water quality despite the presence of a PCRWR laboratory in the city

- The financial situation is extremely critical, the water supply and sewerage services being heavily subsidized. (World Bank and government of Punjab, 2006).

\section{Municipality's Response and Actions of complaints (In-depth Interviews)}

Toaddress the local problems and complaints of the city, the municipalities are playing important roles in management. Responding to complaints is a significant responsibility of local governments providing them with a relevant step to put democratic values at local level into practice, and to facilitate the achievement of more sustainable governance. (Carvalho and Fidélis, 2011)

Tehsil Officer and Chief Officer have been interviewed to provide further information on the process of received complaints treatment. Three basic questions were the focus of interview.

1. How Municipal Corporation is responding and taking actions against the complaints submitted

2. Is complaint submitting process an easy and approachable tool for every citizen? What is the municipality role for a better system monitoring ?

3. In their opinion, what is the role of young citizen's submitted complaints for better management of Municipal services? 


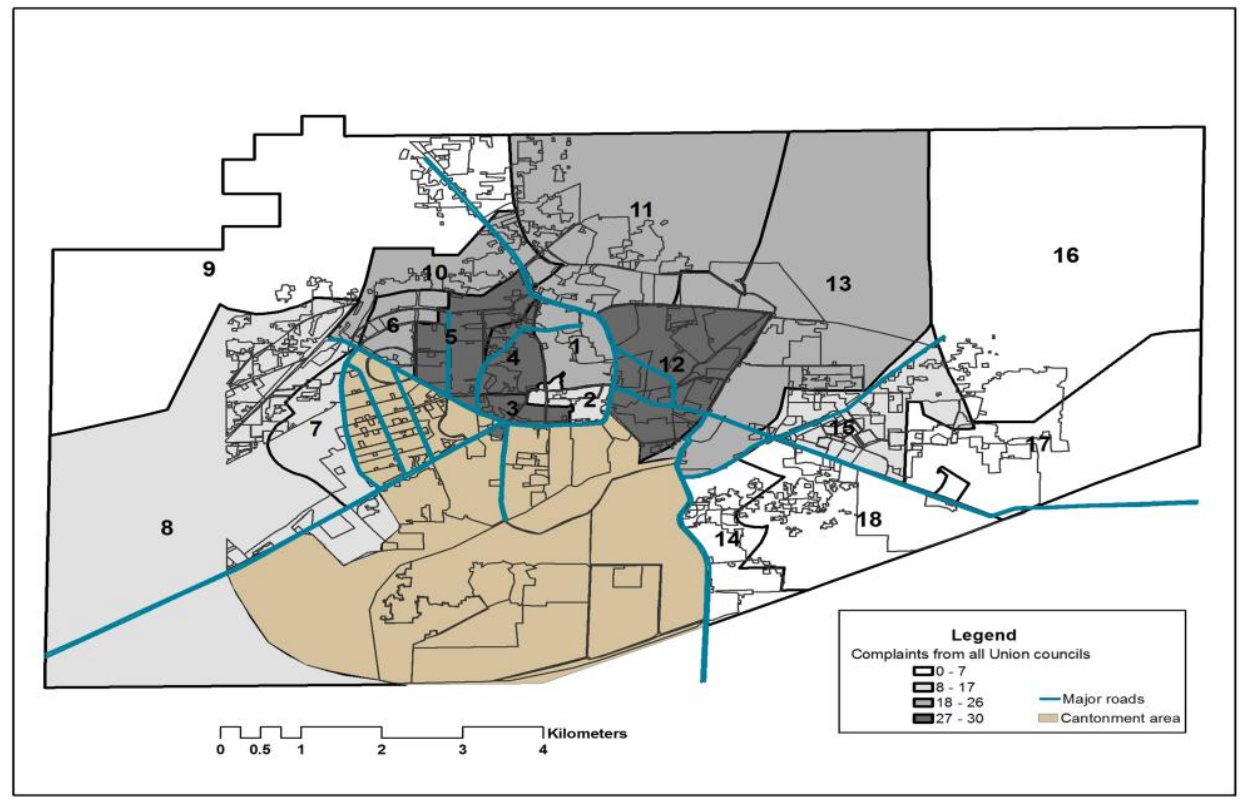

Figure 3. Complaints received from all union councils of city Data Source: Tehsil Municipal Administration (Bahawalpur City)

Table 5: Response of TMA to the received complaints

\begin{tabular}{l|lllll}
\hline $\begin{array}{l}\text { Environmental } \\
\text { problems }\end{array}$ & $\begin{array}{l}\text { Resolved } \\
\text { problems }\end{array}$ & Percentage & $\begin{array}{l}\text { Unresolved } \\
\text { problems }\end{array}$ & percentage & Total \\
\hline $\begin{array}{l}\text { Sewage and } \\
\text { drainage }\end{array}$ & 60 & $23 \%$ & 201 & $77 \%$ & 261 \\
Water supply & 12 & $26 \%$ & 35 & $74 \%$ & 47 \\
Solid wastes & 20 & $74 \%$ & 07 & $26 \%$ & 27 \\
\hline total & 92 & $27 \%$ & 243 & $73 \%$ & 335 \\
\hline Complied by: Author
\end{tabular}

According to them all complaints are managed and resolved by separate division and monthly compiled data is sent to the Punjab Municipal Development Fund company (PMDFC) for their record. Tehsil and chief officer provided details about resolved and unresolved complaints as shown in table 6.

Out of total 261 complaints of sewage problems $23 \%$ are being resolved by TMA on the basis of information provided by the young citizens. Similarly $26 \%$ problems of water supply and $74 \%$ problems of solid wastes are also resolved on the similar basis of information collected through these complaints about the location of problem and kind of problem. In this way, the total number of complaints received in Municipal Corporation from March 2010 to March 2011 was 335 in number, out of which 92 making only $27 \%$ of total are resolved.

Implication of youth complaints also helped to control further problems of the city. The interviews conducted from Tehsil and Chief officer of Municipal Corporation showed that following actions are being taken by the authority for managing different problems
- For controlling sewerage problems, different wastes disposal and recycling units are working at different stations of the city including

- Different water supply schemes are running in different parts of the city by "Southern Punjab basic Urban Services Project TMA (City) Bahawalpur"

- to improve sanitation, disposal of Solid Waste/ Malba and maintaining general cleanliness, a special campaign has been launched

The $2^{\text {nd }}$ part of the interview was meant to draw attention on the role played by the municipality for better monitoring of the system. According to them, current procedure adopted by Municipal Corporation is not quite adequate and easily approachable for every citizen especially for the females. However, as a corrective measure, Punjab Municipal Development Fund Company (PMDFC) is stepping forward to establish complaint cells in its partner TMAs. (Government of Punjab established PMDFC, as a separate agency for municipal development in the Punjab province with the technical and financial assistance of the World Bank). (PMDFC, 2012). 
Table 6: Suggestions for better Youth Participation for environment governance

\begin{tabular}{l|l}
\hline Educating young people & $\begin{array}{l}\text { Environment health, } \\
\text { Environment } \\
\text { infrastructure, importance } \\
\text { of good environment }\end{array}$ \\
\hline $\begin{array}{l}\text { Gathering information } \\
\text { from young people }\end{array}$ & $\begin{array}{l}\text { Complaints, service } \\
\text { satisfaction surveys, } \\
\text { suggestion schemes } \\
\text { Youth conferences, } \\
\text { meetings with } \\
\text { municipalities }\end{array}$ \\
Involving young & $\begin{array}{l}\text { Public policy, leadership } \\
\text { development }\end{array}$ \\
\hline people & $\begin{array}{l}\text { Creating local projects by } \\
\text { pollaborative }\end{array}$ \\
\hline
\end{tabular}

PMDFC initiated a project named "Punjab Municipal services improvement project" under which "complaint tracking system" (CTS) is developed. The major purpose of this system is registration, tracking and resolution of complaints. CTS system helped in increasing the TMA's efficiency of performance. Currently 37 Tehsil and Town Municipal committees are working as partners of PMDFC. Although, Tehsil Municipal Administration of Bahawalpur is also in the process of becoming its partner and by the next year will adopt the same computerized complaint tracking system. PMDFC in their annual report of "Punjab Municipal Services improvement project" July 2010 to June 2011 states that

"Complaints from a specific area or municipal service has been regarded as an indicator of deteriorating service level by the TMA management. Before CTS was launched, TMA management had no quantitative measure to identify deterioration in municipal services standards by category or geographical area. CTS is being used for the identification of problem areas in the TMA. This has been the major use of CTS data besides its direct use as a complaint registration system. Monthly reports of complaints received from the TMAs are analysed by type and location of problem."

The $3^{\text {rd }}$ part of the interview deals with the role of youth complaints for better management of the municipal services. Official authority gave their positive comments about the role of young citizens. According to them, complaints submitted by the young people are more reliable in identifying the problem areas and it clearly shows their positive attitude and concern for constructive solutions to the city problems. According to the chief officer, many young people are interested to work voluntarily for services development projects. Municipal
Authority also aims to motivate the College and University research students to participate in such projects because young people can develop knowledge for problem solving, program planning, and community cooperation through different programs of dialogues and different community change project (Checkoway and Gutiérrez, 2006). Therefore the participation of young people is of fundamental importance for proper environmental governance and management. It is very important to discuss the meaning and significance of participation in a logical manner.

The role of young people in environmental governance process is not only significant through complaints only, moreover keeping in view the four roles of youth in "United Nations World Youth Report 2010" a simple model can be generated categorizing the youth role in five different perspectives

Computerized tracking system will not only help TMA to make the process efficient but also it gave an opportunity to Youth and other citizens for better participation in local environment governance. By using the collected information, the effects of adopted strategies and planning can be tested by conducting service satisfaction surveys and taking suggestions for improvement. The local project can be launched by TMA to engage youth and adults in environment governance process. It will not only provide employment to youth but also will help to train the citizens at early age groups that will support a healthy living environment of city. Therefore, mutual collaboration between local authorities and young citizens is very necessary for improving municipal urban services and better management plans.

\section{Conclusion}

Environment is a very important subject addressed by citizens for various reasons. Young people make a significant share of the urban population, and most affected by the decisions and policies of local government. The research explores the very important component of youth participation in management processes i.e. gathering information about local environment issues in the form of complaints. To submit complaints to the local authority provides opportunity to young citizens to express their views openly about municipal services as well as their management. Citizen satisfaction with the performance of TMA is an important touchstone of quality of municipal services being provided. Unfortunately no adequate administrative mechanism is adopted in the study area for addressing the complaints of citizens. The results in research show that municipality gathered very 
important information about the location and type of environmental problems arising in the city. Moreover there are also many other advantages of gathering information from the complaints. Municipal administration provides a lot of services to its citizens for healthy living conditions. In order to assess their system and self evaluating the complaints become important tool for performance evaluation of TMA. Therefore, complaint system is now in the process of transformation into computerized tracking system from online submission of complaints. It not only made the process easy and fast, but also became helpful in storing and analysing the relevant data for accountability of services as well as for citizen satisfactions.

\section{References}

Asian Development Bank 2008, Country environment analysis, Islamic republic of Pakistan, Government of Pakistan.

Bonaiuto, M, Fornara, F \& Bonnes, M 2006, 'Perceived residential environment quality in middle-and lowextension Italian cities', Revue Européenne de Psychologie Appliquée/European Review of Applied Psychology, vol. 56, pp. 23-34.

Cantrell, R 1980,'A method for investigation of environmental complaints, Journal of Environmental Health, vol. 43, pp. 14-18.

Carvalho, D \& Fidélis, T 2009a,'Environmental complaints in Aveiro, Portugal: actors, concerns, territorial pattern, and resolutions / Reclamações ambientais em Aveiro, Portugal: atores, preocupações, padrão territorial e resoluções', Revista Sociedade E Natureza, vol. 21.

Carvalho, DS \& Fidélis, T 2009b,'The perception of environmental quality in Aveiro, Portugal: a study of complaints on environmental issues submitted to the City Council', Local Environment, vol. 14, pp. 939-961.

Carvalho, DS \& Fidélis, T 2011,'Citizen complaints as a new source of information for local environmental governance', Management of Environmental Quality: An International Journal, vol. 22, pp. 386-40o.

Checkoway, B \& Gutiérrez, LM 2006, Youth participation and community change, Routledge.

Dasgupta, S \& Wheeler, D 1997, Citizen complaints as environmental indicators: evidence from China, World Bank, Policy Research Department, Environment, Infrastructure, and Agriculter Division.

Driskell, D 2002, Creating better cities with children and youth: A manual for participation, Earthscan/James \& James.

Frank, KI 2006, The potential of youth participation in planning, Journal of Planning Literature, vol. 20, p. 351.

Friedmann, J 1999, Urban and regional governance in the Asia Pacific, Institute of Asian Research, University of British Columbia, Vancouver.

Gauthier, M 2003,'The inadequacy of concepts: the rise of youth interest in civic participation in Quebec', Journal of Youth Studies, vol. 6, pp. 265-276.
Gore, CD, Savan, B \& Morgan, A 2004,'Shifts in environmental governance in Canada: how are citizen environment groups to respond?, Environment and Planning C, vol. 22, pp. 605-619.

Harman, J 2005,'The relationship between good governance and environmental compliance and enforcement, Seventh International Conference on Environmental Compliance and Enforcement, pp. 5-13.

Hasan, A \& Ali, AA 1992,'Environmental problems in Pakistan; their origins and development and the threats that they pose to sustainable development', Environment and urbanization, vol. 4, p. 8.

Huang, H \& Miller, GY 2006,' Citizen complaints, regulatory violations, and their implications for swine operations in Illinois', Applied Economic Perspectives and Policy, vol. 28, pp. 89-110.

Johnson, LR, Johnson-Pynn, JS \& Pynn, TM 2007,'Youth civic engagement in China: Results from a program promoting environmental activism', Journal of Adolescent Research, vol. 22, p. 355.

Kosecik, M \& Sagbas, I 2004,'Public attitudes to local government in Turkey: research on knowledge, satisfaction and complaints', Local Government Studies, vol. 30, pp. 360-383.

Lemos, MC \& Agrawal, A 2006,'Environmental governance', Annu. Rev. Environ. Resour., vol. 31, pp. 297-325.

Markell, DL 2004,'Enhancing Citizen Involvement in Environmental Governance', Natural Resources $\mathcal{E}$ Environment, vol. 18, pp. 49-52.

NA Tehsil Municipal Administration Bahawalpur, viewed on April $19^{\text {th }}$ 2012, http://www.tmabwpcity.com/

Ostrom, E 1990, Governing the commons: The evolution of institutions for collective action, Cambridge University Press.

Paavola, J 2007,'Institutions and environmental governance: A reconceptualization', Ecological economics, vol. 63, pp. 93-103.

Qazi, SA 2006, Population geography, New Delhi, APH Pub. Corp.

Punjab Municipal Development Fund Company 2012, Home Page, viewed on April $19^{\text {th }}$ 2012,

http://www.pmdfc.org.pk/.

Qi, Y, Xue, L \& Zhang, L 2007, Governance approach to China's environmental challenges: Towards a theoretical synthesis', Frontiers of Environmental Science $\mathcal{E}$ Engineering in China, vol. 1, pp. 385-400.

Renn, O, Webler, T \& Wiedemann, PM 1995, Fairness and competence in citizen participation: Evaluating models for environmental discourse, Springer.

Shafqat, A 2011,'The role of the municipality in waste water management in Bahawalpur city', Management of Environmental Quality: An International Journal, vol. 22, pp. 282-291.

UNDP 2012, United Nations Development Program, accessed on April $19^{\text {th }}$ 2012, http://undp.org.pk/undp-and-theyouth.html.

United Nations 2010, World youth report, Youth and Climate Change. 